Krzysztof Bieliński C.Ss.R ${ }^{1}$

Accademia Alfonsiana

\title{
Przyjęcie wykluczonych do wspólnoty zbawienia na przykładzie Dz 15, 1-35
}

Łukaszowa narracja o spotkaniu Żyda Piotra i poganina Korneliusza z Dz 10, 1 - 11, 18 ukazuje ewolucyjne dojrzewanie sumienia chrześcijańskiego, które doprowadziło Piotra, a w konsekwencji także pierwotny Kościół do zrozumienia, iż Bóg ani nie jest stronniczy, ani też nikogo nie wyklucza ze wspólnoty zbawienia. Autor Dziejów Apostolskich, historyk i teolog, „pozwala zrozumieć, w jaki sposób, za pośrednictwem misji świadków Chrystusa, uniwersalizm zbawczy wpisany został w historię", a także „ukazuje teologiczny fundament tego uniwersalizmu”. Z wydarzeniem w Cezarei Nadmorskiej, paradygmatycznym, gdy chodzi o doświadczenie chrześcijańskie, nie został jednak przezwyciężony konflikt wywołany interpretacją Prawa i tradycji judaistycznej. Rozdziały 13 i 14 Dziejów opowiadają, jak Paweł i Barnaba, kolejne dwie znaczące postaci w historii początków chrześcijaństwa, powracają z pierwszej akcji

1 Krzysztof Bielinski CSsR - prezbiter Zgromadzenia Najświętszego Odkupiciela; uczeń prof. Joachima Gnilki; doktor teologii biblijnej Uniwersytetu Ludwika Maximiliana w Monachium w Niemczech (2001); aktualnie profesor stabile w Akademii Alfonsjańskiej (Accademia Alfonsiana), Instytucie Wyższym Teologii moralnej Papieskiego Uniwersytetu Laterańskiego w Rzymie. E-mail: kbielinski@alfonsiana.org.

2 D. Marguerat, E. Steffek, L'avvento della salvezza universale in Luca-Atti, w: Una salvezza a misura dell'universo. Scritti in onore di Gérard Rossè, a cura di G. Ibba, Roma 2015, s. 145. 
misyjnej w diasporze żydowskiej. Zwołują oni wspólnotę Kościoła lokalnego w Antiochii i relacjonują, w jaki sposób Bóg otworzył poganom

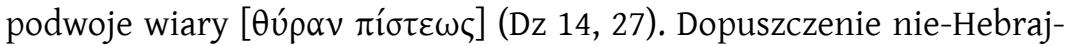
czyków do wspólnoty Kościoła na pełnych prawach, bez wymagania od nich przestrzegania Prawa oraz obrzezania, nie sprawiłoby żadnego problemu, jak wynika z referowanej tu Łukaszowej narracji ${ }^{3}$, gdyby nie interwencja grupy chrześcijan, tzw.judaizantes, nieakceptujących tej innowacji (Dz 15, 1). Proponuje się barierę Prawa, wobec którego powstaje konflikt pomiędzy Pawłem i Barnabą a przedstawicielami radykalnego skrzydła judeochrześcijaństwa z Jerozolimy ${ }^{4}(\mathrm{Dz} 15,5)$. Nie mogąc rozwiązać problemu dotyczącego roli obrzezania i Prawa w przypadku chrześcijan wywodzących się z pogaństwa, frakcje postanawiają udać się do Jerozolimy, aby razem z „tymi, którzy apostołami stali się pierwej niż [Paweł]" (Gal 1, 17b), dokonać rozeznania eklezjalnego i znaleźć rozwiązanie tej kryzysowej sytuacji ${ }^{5}$.

W oparciu o Łukaszowe opowiadanie o tzw. soborze w Jerozolimie z Dz 15, 1-35 przeanalizujemy kluczowe doświadczenie eklezjalne, akt decyzyjny pierwotnego Kościoła, polegający na akceptacji uniwersalizmu zbawczego na podstawie wiary w Jezusa Chrystusa. Postanowienie jerozolimskie o przezwyciężeniu odległości, nieufności i przyjęciu pogan do wspólnoty zbawionych przyniosło ze sobą „komunię stołu” między eks-Hebrajczykami i ekspoganami, a także „aprobatę stanowiska pastoralnego ukierunkowanego na zachowanie jedności Kościoła, wymagającego praktycznego kompromisu: etnochrześcijanie zachowają minimum przepisów obrzędów żydowskich z uwagi na sumienie praktykujących

3 Swobodne, nieobłożone uprzednimi warunkami przyjmowanie pogan do Kościoła w Antiochii budziło niepokój w Jerozolimie. Antiochia, w której istniał najważniejszy po Jerozolimie Kościół najstarszego chrześcijaństwa, rozstrzygnęła już kwestię dotyczącą zasad przyjmowania pogan, opowiadając się za odrzuceniem skrępowań, otwierając drogę dla misji wśród narodów. Por. J. Gnilka, Pierwsi chrześcijanie. Źródła i początki Kościoła, Kraków 2004, s. 346 i 350.

4 Werset 5 precyzuje, iż opozycja składa się z ,niektórych nawróconych ze stronnictwa faryzeuszów". Wyznając Jezusa Chrystusa, nadal nakładają na każdego wierzącego mężczyznę konieczność obrzezania i przestrzegania Prawa Mojżeszowego. Por. D. Marguerat, Gli Atti degli Apostoli. 2 (13-28), Bologna 2015, s. 98.

5 Por. R. Fabris, Atti degli Apostoli, Brescia ${ }^{6} 2004$, s. 99. 
judeochrześcijan"6. Jak trafnie ujął to Rinaldo Fabris, w Jerozolimie podjęte zostały niektóre „normy dyscyplinarne wspomagające współżycie we wspólnotach mieszanych [...]. Normy te mają znaczenie «zbawcze» tylko w tym sensie, iż poprzez ich zachowywanie wyraża się i aktualizuje jedność i solidarność chrześcijańska oparta na wierze"

Zasadniczym celem artykułu jest ukazanie sposobu postępowania wspólnoty Kościoła w konfrontacji z wielkim wyzwaniem teologicznym, pastoralnym i normatywno-dyscyplinarnym, jakim dla chrześcijaństwa początków był etyczny problem przyjęcia do wspólnoty zbawienia wykluczonych do tej pory pogan. Jednocześnie zamierzamy na podstawie tego paradygmatycznego doświadczenia Kościoła zaproponować także Pismo Święte jako konieczny punkt odniesienia dla nowych, aktualnych problemów etycznych ${ }^{8}$.

Zagadnienie przeanalizujemy w trzech punktach. Na początku wydaje się rzeczą konieczną zdefiniowanie pojęcia decyzji moralnej w jej trójwymiarowości czasowej. Centralny drugi punkt dedykujemy Łukaszowej narracji z Dz 15, 1-35 o tzw. soborze w Jerozolimie. Ukażemy paradygmat procesu eklezjalnej decyzji, którego efektem stało się pełne włączenie do wspólnoty Kościoła wykluczonych etnochrześcijan. Badanie zakończymy aktualnymi wskazaniami na temat rozeznawania wspólnotowego zawartymi w dokumencie Papieskiej Komisji Biblijnej Biblia a moralność.

\section{Wymiar czasowy i wspólnotowy decyzji moralnej}

„Człowiek podejmuje decyzje osobiste teraz, w świetle i pod wpływem wczoraj, a także w perspektywie jutra"'. Twierdzenie Marciano Vidala na temat trójwymiarowości czasowej ludzkiego istnienia stanowi dobre wprowadzenie dla przedstawienia istoty osobowego aktu decyzyjnego.

6 G. Barbaglio, Conflittualità e riconciliazione nelle prime comunità cristiane, w: G. Barbaglio, Emozioni e sentimenti di Gesù, Bologna 2009, s. 208.

7 R. Fabris, Atti degli Apostoli, dz. cyt., s. 101.

8 Por. Papieska Komisja Biblijna, Biblia a moralność. Biblijne korzenie postępowania chrześcijańskiego, Kielce 2009, s. 154.

9 M. Vidal, Manuale di etica teologica.1. Morale fondamentale, Assisi 1994, s. 357. 
Teoria czasowego wymiaru ludzkiego aktu decyzyjnego w aktualnej refleksji moralnej stanowi w naszym przekonaniu konieczny punkt odniesienia dla prawidłowej analizy interesującej nas w artykule etycznej perspektywy Łukaszowego opowiadania o soborze w Jerozolimie. W czasie tego zgromadzenia, dzięki złożonemu procesowi rozeznawania wspólnotowego, pokonany został wielki kryzys. Analiza tej fundamentalnej decyzji pierwotnego Kościoła pozwoli wniknąć w proces dialogu z różnymi przekonaniami drugich oraz procedurę podejścia wspólnoty wierzących do tego newralgicznego wyzwania ówczesnej rzeczywistości w odniesieniu do prawdy moralnej.

Perspektywę antropologiczną decyzji moralnej osoby, fakt, iż każde postępowanie człowieka jako istoty historycznej realizuje się w trzech wymiarach w relacji do czasu: w teraz, w świetle i pod wpływem wczoraj oraz w perspektywie jutra, ilustruje następujący schemat:

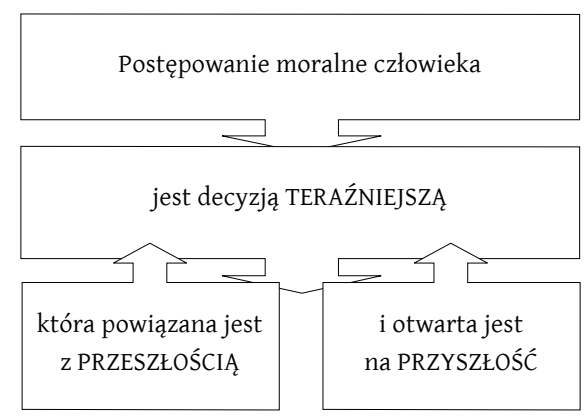

Ta trójwymiarowość czasowa decyzji ludzkiej, jej antropologiczna perspektywa nabywa głębszego znaczenia, jeżeli odnieść ją do doświadczenia chrześcijańskiego, uwzględniając tym samym wymiar teologiczny decyzji człowieka wierzącego ${ }^{10}$. Decyzję moralną trzeba nam zatem uzupełnić o perspektywę teologiczną. Podkreśla ją cytowany wyżej Vidal, konstatując: „Poprzez swoją wiarę chrześcijanin jest współczesny

10 Kultura postnowoczesna redukująca człowieka do prawd użytecznych, do linearnej wizji czasu nie ma perspektywy transcendencji ani też odniesienia do niej. 
Chrystusowi, a jednocześnie otwiera się na horyzonty eschatologiczne; tym wszystkim musi żyć w «decyzji» podejmowanej w teraźniejszości”" Wiara jest tą rzeczywistością, dzięki której człowiek przyjmuje i interioryzuje prawdę eschatologiczną Chrystusa. Trójwymiarowość czasową postępowania człowieka wierzącego, uzupełnioną o aspekt teologiczny, zilustrować można następująco:

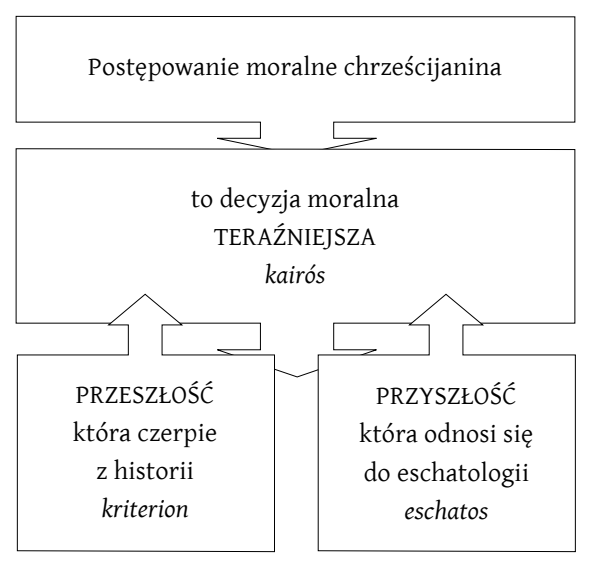

Jak wynika z tego graficznego przedstawienia, akt decyzji moralnej chrześcijanina jako indywiduum oraz chrześcijan jako wspólnoty wierzących uwzględnia trzy kategorie czasowe: kairós (каıрóৎ), kriterion

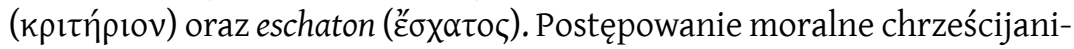
na jest uwarunkowane wydarzeniami historii zbawienia, faktami, w których Bóg się objawił, dał się poznać, wszedł w historię ludzkości poprzez swoje słowa i czyny. $Z$ tego powodu historia zbawienia jest kryterium (кpıтńpıov), normą niezbywalną w osądzie. kpııńpıov określa przede wszystkim wydarzenie Chrystusa, centralne w całej historii zbawienia. Chrześcijanin żyje bowiem w teraźniejszości, przyjmując Jezusa jako najwyższy model swojego postępowania moralnego, a czyni to zawsze w oczekiwaniu pełni objawienia się Kyriosa w eschatologii.

\footnotetext{
11 M. Vidal, Manuale di etica teologica, dz. cyt., s. 358.
} 
Uczeń Chrystusa rozpoznaje w świetle objawienia problemy i wyzwania, jakie pojawiają się w jego „teraz”, stara się czynić dobro i unikać zła. Moralność chrześcijanina jest zatem moralnością kaıpós. Decyzja moralna podejmowana jest w teraźniejszości, przeżywanej w pełni objawienia i jako rezultat historii zbawienia. Kaıpós to „czas uprzywilejowany, zbawienia", któremu początek dało wydarzenie Chrystusa, czas decyzji, jaki pozostaje do nadejścia kulminacyjnego momentu procesu eschatologicznego: paruzji i sądu ostatecznego. Osąd moralny chrześcijanina i jego adekwatne postępowanie etyczne zależą od koıрós. Wiedza o tym, jakie znaczenie ma każde wydarzenie w historii zbawienia, jest tym, co powinno determinować osąd moralny chrześcijanina, a także akty, które z niego wypływają. Dlatego wymaga się od ucznia Chrystusa zdolności rozeznawania, ono bowiem jest sprawnością ewaluacyjną

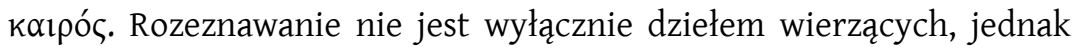
to chrześcijanin ma w tym względzie pomoc Ducha Świętego, a w konsekwencji zdolność oceny każdej sytuacji w świetle Ewangelii ${ }^{12}$. Natomiast

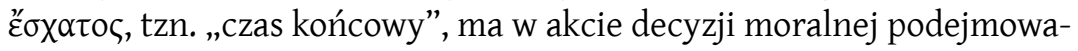
nej w teraźniejszości znaczenie otwarcia chrześcijanina na perspektywę eschatologiczną. Chodzi tu o uwzględnienie znaków czasu, które interpretować należy w świetle Ewangelii, za pomocą cnót czasów ostatecznych: nadziei, czujności i gotowości. „Rodzi się moralność czuwania i uwagi wobec wydarzeń, a nie moralność zamknięta sama w sobie"13.

Po tym ogólnym spojrzeniu na decyzję moralną w jej trójwymiarowości czasowej zwróćmy jeszcze uwagę na jej wymiar wspólnotowy. Sięgniemy w tym celu po pracę Francesca Maceriego ${ }^{14}$. Życia i misji Kościoła nie można oddzielić od Ducha Świętego i Jego dzieła. Kościół jest pobudzany przez Ducha do otwarcia we wzajemności sumień na przyjęcie woli Bożej, która polega na odkupieniu i uleczeniu poranionego świata, uczynieniu wierzących w Chrystusa jednym ludem Bożym ${ }^{15}$. W konstytucji duszpasterskiej o Kościele w świecie

12 Por. M. Vidal, Manuale di etica teologica, dz. cyt., s. 359.

13 M. Vidal, Manuale di etica teologica, dz. cyt., s. 360.

14 F. Maceri, La coscienza morale filiale, w: Figli nel Figlio. Una teologia morale fondamentale, a cura di R. Tremblay, S. Zamboni, Bologna ${ }^{2} 2016$, s. 225-248.

15 Por. Sobór Watykański II, konst. Lumen gentium, 2. 
współczesnym Gaudium et spes Sobór Watykański II konstatuje w tym względzie: „Kościół zawsze ma obowiązek badać znaki czasów i wyjaśniać je $\mathrm{w}$ świetle Ewangelii ${ }^{16}$ [...] i stara się $\mathrm{w}$ wydarzeniach, potrzebach i pragnieniach, w których uczestniczy z resztą ludzi naszej doby, rozpoznać, jakie $\mathrm{w}$ nich mieszczą się prawdziwe znaki obecności lub zamysłów Bożych”17. W komunii eklezjalnej „przez wierność sumienia chrześcijanie łączą się z resztą ludzi w poszukiwaniu prawdy i rozwiązywaniu w prawdzie tylu problemów moralnych, które narzucają się tak w życiu jednostek, jak i we współżyciu społecznym"18. Zatem w dialogu z historią, badaniu znaków czasu i szukaniu prawdy Kościół odnosi do Boga, do perspektywy historyczno-zbawczej to wszystko, co wydarza się w świecie. Jesteśmy w obecności aspektu eklezjalnego, wspólnotowego i moralnego kaıрós, tego jego wymiaru, który podkreśla akt decyzji moralnej w teraźniejszości.

Dialog eklezjalny sytuuje się na drodze, którą Duch Święty otworzył i otwiera nieustannie w historii. We wspólnocie Kościoła otwartej na świat, który niesie ze sobą nowe wyzwania i pytania, sumienie wierzących otwiera się na rozpoznanie prawdy moralnej (tzn. sposobu postępowania) w odniesieniu do problemów szczegółowych i praktycznych. Prawda moralna wynika ze spotkania między przeznaczeniem

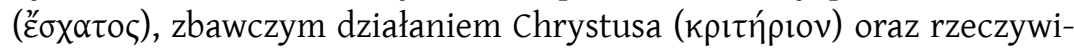
stością wymagającą przemiany (koıрóৎ) i ostatecznie „staje się wezwaniem do pojedynczej osoby, aby przybliżyła się i otworzyła się tu i teraz na odkupienie" 19 .

Przygotowani przez powyższe sprecyzowania dotyczące decyzji moralnej, możemy przejść do drugiego punktu artykułu, w którym skoncentrujemy naszą uwagę na procesie decyzji wspólnotowej, ukazanej w opowiadaniu o zebraniu w Jerozolimie (Dz 15, 1-35).

\footnotetext{
Sobór Watykański II, konst. Gaudium et spes, 11.

Sobór Watykański II, konst. Gaudium et spes, 14.

Sobór Watykański II, konst. Gaudium et spes, 16.

F. Maceri, La coscienza morale filiale, dz. cyt., s. 248.
} 


\section{Sobór w Jerozolimie w Dz 15, 1-35: proces włączania wykluczonych do wspólnoty zbawienia}

Rozdział 15 Dziejów uznawany jest za „centrum narracji i teologii drugiej księgi Łukasza, centrum, które stanowi zwrot w Dziejach Apostolskich"20. Jest opowiadaniem obrazującym moment uznania, zalegalizowania misji Kościoła wobec świata pogańskiego na fundamencie afirmacji, iż zbawia nie Prawo, lecz łaska Chrystusa, tzn. wiara w Niego. Zagadnienie dyskutowane w czasie soboru w Jerozolimie stanowi podstawową trudność, jaką rozstrzygnęło chrześcijaństwo w pierwszych dwóch wiekach swojego istnienia.

Dzieje Apostolskie aż do rozdziału 15 informują o stale podejmowanej ewangelizacji pogan: zainicjowanej przez spotkanie Piotra z domem Korneliusza (Dz 10, 1-48), kontynuowanej przez Kościół w Antiochii (Dz 11, 20) i rozpowszechnionej przez Pawła i Barnabę (Dz 13 - 14). Wezwanie, przed jakim staje Kościół w Dz 15, 1-35 dotyczy zasadniczej kwestii soteriologicznej, konieczności obrzezania według zwyczaju Mojżesza dla bycia zbawionym. Misja wśród pogan już spotkała się z wrogością ze strony synagogi (Dz 13, 45.50; 14, 2.5.19), teraz zaś prowokuje kryzys wewnątrzkościelny. Korzeniem konfliktu staje się protest judeochrześcijan przeciwko pojmowaniu i głoszeniu zbawienia bez konieczności zachowania przepisów Prawa i praktyki obrzezania (Dz 15, 5).

Struktura Łukaszowej narracji ma doskonałe proporcje: wersety 1-3 stanowią prolog, który historycznie sytuuje zaistniały konflikt; wersety 30-35 tworzą epilog opowiadający o osiągnięciu porozumienia i odnalezieniu pokoju w Antiochii, co wyrażone zostaje dekretem; będące centrum narracji wersety 4-29 traktują o spotkaniu w Jerozolimie. Na tę część opowiadania składają się dwa przemówienia: wersety 7-11 to mowa Piotra $^{21}$, natomiast wersety 13-21 to odpowiedź Jakuba. Odwołanie się

20 G. Rossé, Atti degli Apostoli commento esegetico e teologico, Roma 1998, s. 557.

${ }^{21}$ Mowy stanowią około jedną trzecią treści Dziejów. Są one literacko-teologicznymi kompozycjami autora. Łukasz wzoruje się na historiografii antycznej. Funkcją i zadaniem mów jest komentowanie i objaśnianie wydarzeń historiozbawczych. Por. S. Szymik, Mowy w Dziejach Apostolskich, w: Encyklopedia katolicka, t. 13, red. E. Gigilewicz, Lublin 2009, kol. 377-378. 
do konfliktu (wersety 4-5) poprzedza pierwsze wystąpienie, natomiast oświadczenie o jego rozwiązaniu następuje po drugim (wersety 22-29). Opowiadanie koncentruje się na tzw. „dekrecie apostolskim”, na którym ogniskuje się także przemówienie Jakuba (Dz 15, 20). Dekret zostaje powtórzony w liście skierowanym do wspólnot Kościoła (Dz 15, 29).

\subsection{Czas obecny: konflikt w Antiochii (Dz 15, 1-3)}

Dzieje odzwierciedlają ogromne napięcia, jakie zaistniały we wczesnym Kościele odnośnie do warunków, na jakich poganie mieli być przyjmowani do wspólnoty zbawionych. A chociaż nakaz Jezusa w Dz 1, 8 (por. Łk 24, 47) wskazuje wyraźnie na włączenie pogan do ludu Bożego, pierwsi chrześcijanie nie rozumieli jeszcze, w jaki sposób ma się to dokonać. Przykładem tego jest wspomniany już wyżej epizod z Korneliuszem, „bojącym się Boga” poganinem (Dz 10, 2). Kiedy Piotr wraca z Cezarei do Jerozolimy, tamtejsi judeochrześcijanie nie robią mu wyrzutów z powodu nawrócenia poganina, ale dlatego, że zasiadł przy wspólnym stole i jadł z nieobrzezanymi (Dz 11, 2-3). Przyjęcie pogan do wspólnoty wyznawców Jezusa było zatem dla nich rzeczą oczywistą, wynikającą z nakazu Pana. Nie rozumieli natomiast, w jaki sposób miało się to dokonać, ponieważ Prawo zabraniało im wszelkich kontaktów z nieobrzezanymi. Z narracji Dziejów wynika, iż włączenie do tej pory wykluczonych pogan do ludu Bożego odbyło się bez świadomego, zamierzonego planu ze strony przywódców Kościoła, lecz za natchnieniem i zaskakującym też działaniem Ducha Świętego ${ }^{22}$.

Wersety wprowadzające w opowiadanie (1-3) informują o przyjęciu delegacji antiocheńskiej przez cały Kościół w Jerozolimie (apostołów i starszych). Posłańcy ze wspólnoty antiocheńskiej zdają relację: „opowiedzieli też, jak wielkich rzeczy Bóg przez nich dokonał”. Opozycja składająca się z "niektórych nawróconych ze stronnictwa faryzeuszów” $($ Dz 15, 5) domaga się przestrzegania obrzezania i Prawa Mojżeszowego.

22 W. Rakocy, „Będziecie moimi świadkami...” (Dz 1, 8). Dzieje Apostolskie, w: Wprowadzenie w myśl i wezwanie ksiąg biblijnych. 9. Dzieje Apostolskie. Listy św. Pawła, red. J. Frankowski, S. Mędala, Warszawa 1997, s. 36. 
W ich opinii wierzący w Chrystusa są częścią Izraela, grupą należącą do wielkiego Przymierza Abrahama, dlatego wiara w Jezusa Mesjasza nie dyspensuje etnochrześcijan od warunków przynależności do ludu zbawienia. Obrzezanie i zachowanie przepisów Prawa mają być w dalszym ciągu ceną pełnej integracji z ludem Bożym. Konfrontacja tych różnych stanowisk wymaga pogłębionej analizy ze strony Kościoła.

\subsection{Historia jako kryterium oceny: debata w Jerozolimie (Dz 15, 4-29)}

\subsubsection{Przemówienie Piotra - konsekwencje etyczne} uniwersalizmu zbawczego (Dz 15, 7-12)

Piotr zabiera głos w imieniu apostołów, czyni to z autorytetem, który wykracza poza jego osobiste przekonania. Należy zauważyć, iż to jego „synodalne” przemówienie zawiera cztery elementy mowy u zas a d niającej (deliber aty w nej) według kanonu retoryki greckiej $^{23}$. Mowa deliberatywna jako gatunek literacki „ma za okoliczność spór o to, jaką podjąć decyzję. Gdy różne osoby i stronnictwa różnią się w ocenie sytuacji oraz poglądach na to, co należy czynić, mówca przekonuje, że jego rozwiązanie problemu jest najlepsze" ${ }^{24}$. Warto dodać, w nawiązaniu do zagadnienia wymiaru czasowego decyzji omówionego w punkcie 1, iż „rzeczywistym okresem czasu, do którego odnoszą się sprawy z tego genus, jest przyszłość, lecz aby posiąść wiedzę o sprawach przyszłych, konieczne jest zajmowanie się sprawami przeszłymi i teraźniejszymi”25.

23 Prawidłowo skonstruowana mowa składa się z pięciu części: wstępu (łac. exordium), narracji (łac. narratio), argumentacji (łac. probatio), refutacji (łac. refutatio - zbijanie zarzutów) i zakończenia (łac. conclusio). Z tych pięciu części można w niektórych okolicznościach pominąć wstęp. Nie należy go stosować, jeżeli temat wypowiedzi jest niedługi lub oczywisty. Por. H. Lausberg, Retoryka literacka. Podstawy wiedzy o literaturze, tłum. A. Gorzkowski, Bydgoszcz 2002, § 262.

${ }_{24}$ R. Pindel, Mowy obronne św. Pawła w Dziejach Apostolskich. Analiza retoryczna Dz 24 i 26 w kontekście zastosowania retoryki w biblistyce, Kraków 2012, s. 86.

25 H. Lausberg, Retoryka literacka, dz. cyt., § 228. 


\begin{tabular}{|l|l|}
\hline EXORDIUM (w. 7b) & Autorytet mówcy \\
\hline NARRATIO (ww. 8-9) & $\begin{array}{l}\text { Nawiązanie do działania Boga w nawróceniu } \\
\text { Korneliusza } \\
\text { Poganin z Cezarei został ochrzczony przez } \\
\text { Piotra bez obrzezania i zachowania Prawa }\end{array}$ \\
\hline PROBATIO (w. 10) & $\begin{array}{l}\text { Konsekwencje etyczne: nie należy wymagać } \\
\text { od etnochrześcijan zachowywania Prawa }\end{array}$ \\
\hline CONCLUSIO (w. 11) & $\begin{array}{l}\text { Orędzie soteriologiczne: darmowość zbawienia } \\
\text { objawiona w Jezusie Chrystusie }\end{array}$ \\
\hline
\end{tabular}

Piotr argumentuje, rozpoczynając od przeszłości, uwzględnia kriterion w akcie decyzji. Adekwatnie do ówcześnie stosowanych zasad retoryki, rozpoczyna od wskazania tytułu upoważniającego go do zabrania głosu. Podkreśla, iż jego głoszenie Ewangelii opiera się na fundamencie decyzji Boga, który wybrał go do ewangelizacji narodów. Po tym exordium ma miejsce narratio (ww. 8-9). Jest ono pouczającą relekturą wydarzenia w Cezarei. Piotr odwołuje się do historii w domu Korneliusza, gdzie Bóg, „znawca serc”, udzielił nie-Żydom tego samego Ducha, którego wcześniej wylał na Kościół w Jerozolimie (w. 8). Słuchacze zostają wezwani do refleksji nad fenomenem narodzin wiary pogan. Przypominając sobie wydarzenie wylania na nich Ducha Świętego, które stało się momentem fundacyjnym Kościoła, mają zaakceptować prawdę, iż „Bóg nikogo nie dyskryminuje” (w. 9). Apostoł wcześniej już dwukrotnie sformułował ten aksjomat: „Przekonuję się, że Bóg naprawdę nie ma względu na osoby. Ale w każdym narodzie miły jest $\mathrm{Mu}$ ten, kto się Go boi i postępuje sprawiedliwie" (Dz 10, 34-35; 11, 12). Piotr wyjaśnia, iż wydarzenie zesłania Ducha Świętego na dom Korneliusza było dla niego objawieniem uniwersalizmu zbawczego. Mówi przy tym o „oczyszczeniu serc” pogan (w. 9). Pojawiająca się tu po raz pierwszy koncepcja aktu oczyszczającego, urzeczywistnionego przez Boga na poganach, służy Piotrowi jako argument do odrzucenia żądań frakcji judaizujących (Dz 15, 5). Twierdzenie, że Bóg dokonał oczyszczenia serc etnochrześcijan, oznacza z jednej strony, iż czystość jest darem Boga, a nie rezultatem wysiłku człowieka, zachowywania przez niego przepisów Prawa. Z drugiej zaś wskazuje, iż prawo separacji na to, co rytualnie czyste i nieczyste, traci 
swoją ważność w obliczu zbawienia oferowanego w Chrystusie. Pytanie retoryczne: „Dlaczego więc teraz Boga wystawiacie na próbę, wkładając na uczniów jarzmo, którego ani ojcowie nasi, ani my sami nie mieliśmy siły dźwigać?" (w. 10) pozwala Apostołowi wyciągnąć wniosek natury soteriologicznej: Bóg nie dyskryminuje, nie czyni różnicy pomiędzy obrzezanymi i nieobrzezanymi. Piotr stawia judeochrześcijanom zarzut: jeżeli tak Bóg uczynił, to jakim prawem się opieracie? W tekście pojawia się

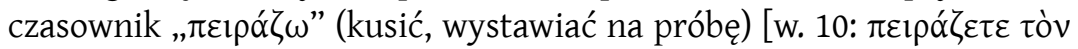
$\theta \varepsilon o ̀ v]$, który jest pojęciem biblijnym i oznacza „wystawiać Boga na próbę, prowokować" (por. Ez 15, 25; 17, 2; Lb 14, 22). Podobnie jak w historii Ananiasza i Safiry z Dz 5, 9, „wystawiać Boga na próbę” oznacza także tutaj, opierać się działaniu Ducha Świętego ${ }^{26}$.

Apostoł podsumowuje przemówienie wyznaniem wiary w uniwersalny charakter zbawienia, które jest łaską (w. 11). Powtarza tu terminy soteriologiczne obecne już w Dz 10, 34-35: „wszyscy będziemy zbawieni przez łaskę Pana Jezusa tak samo jak oni”. Należy zauważyć zmianę kolejności, gdy chodzi o beneficjentów zbawienia. Piotr stwierdza, iż judeochrześcijanie są zbawieni w taki sam sposób jak poganie. Akcent pada tu na sformułowanie „tak samo”. Oznacza to, iż to judeochrześcijanie zostają zaproszeni przez Apostoła, aby przemyśleli korzenie swojej wiary, odkrywając bardziej dar łaski niż przylgnięcie do Prawa. To jest centralne przesłanie przemówienia Piotra: nie należy zatem zabraniać innym czegoś, co odkrywa się u korzeni własnej wiary, tzn. jej darmowości. Warto zauważyć, że twierdzeniem dotyczącym darmowości zbawienia ofiarowanego w Chrystusie Łukasz każe zniknąć Piotrowi z narracji Dziejów.

26 Podobnie Paweł odsyła Galatów do początków ich wiary, aby odkryli bardziej łaskę niż posłuszeństwo Prawu (Gal 3,2). Twierdzi on, że „na tych wszystkich, którzy polegają na uczynkach Prawa, ciąży przekleństwo”, ponieważ nie są w stanie „wypełnić wytrwale wszystkiego, co nakazuje wykonać Księga Prawa” (por. Gal 3, 10). Niepowodzenie w posłuszeństwie wobec Prawa to niezbywalny motyw argumentacji Pawła w kwestii usprawiedliwienia. Potwierdza też, iż wszyscy zostali usprawiedliwieni przez łaskę (Rz 3, 24). Paweł sięga po terminologię usprawiedliwienia, podczas gdy Piotr w Dz 15, 11 posługuje się terminologią zbawienia. To, co Łukasz wkłada w usta Piotra, jest sformułowaniem nie-Pawłowym prawdy pochodzącej od Pawła, sformułowaniem post-Pawłowym motywu nieodłącznego od jego soteriologii. Por. D. Marguerat, Gli Atti degli Apostoli. 2 (13-28), dz. cyt., s. 102. 


\subsubsection{Przemówienie Jakuba - uzasadnienie skrypturystyczne}

uniwersalizmu zbawczego oraz „dekret apostolski” (Dz 15, 13-21)

Drugi etap „debaty synodalnej” na temat przyjęcia wykluczonych do wspólnoty Kościoła to przemówienie Jakuba (Dz 15, 13-21). Skoro autor Dziejów go bliżej nie przedstawia, to jest oczywiste, że czytelnicy dobrze znają tę postać ważną dla jerozolimskiej wspólnoty uczniów Jezusa pierwszego wieku, składającej się wyłącznie z judeochrześcijan ${ }^{27}$. Jest rzeczą oczywistą iż przemówienie Jakuba to dzieło redakcyjne Łukasza. Mowa przedstawiciela wspólnoty jerozolimskiej streszcza myśl Piotra, umocowuje je cytatem z Pisma oraz wydobywa z niego konkretne zastosowanie: tzw. „dekret apostołów”. Struktura przemówienia przedstawia się następująco:

\begin{tabular}{|c|c|}
\hline Wprowadzenie: w. 13 & $\begin{array}{l}\text { „A gdy i oni umilkli, zabrał głos Jakub i rzekł: «Posłu- } \\
\text { chajcie mnie, bracia!»”. }\end{array}$ \\
\hline Narracja: w. 14 & 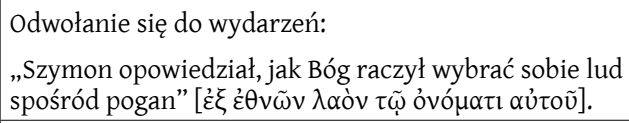 \\
\hline Argumentacja: ww. 15-18 & $\begin{array}{l}\text { Uzasadnienie skrypturystyczne ewangelizacji uniwer- } \\
\text { salnej } \\
\text { - Am 9, } 11 \text { (LXX): Eschatologiczna restauracja króle- } \\
\text { stwa Dawidowego (metafora „przybytek Dawida”); } \\
\text { - Am 9, } 12 \text { (LXX): Pierwotny projekt Boży (termin } \lambda \alpha o ́ \varsigma) ;\end{array}$ \\
\hline Wniosek: ww. 19-21 & $\begin{array}{l}\text { ww. 19-20: Decyzja } \\
\text { - Autorytet Tory; } \\
\text { - „Dekret apostołów” = Kodeks moralny chrześcijan; } \\
\text { w. 21: Uzasadnienie decyzji } \\
\text { - Autorytet Mojżesza, który zobowiązuje pogan jedy- } \\
\text { nie do czterech zakazów (por. Kpł 17-18) }\end{array}$ \\
\hline
\end{tabular}

27 Po odejściu Szymona Piotra stanowisko kierownicze w Kościele jerozolimskim przejął brat Pański Jakub, któremu ukazał się zmartwychwstały Jezus (1 Kor 15, 7; por. Dz 12, 17; 15, 13; 21, 18; Gal 1, 19; 2, 9 i 12). Otrzymał on przydomek „sprawiedliwego”, został ukamienowany w roku 62 pod rządami najwyższego arcykapłana Ananiasza. Por. J. Gnilka, Pierwsi chrześcijanie, dz. cyt., s. 335. 
Od początku filar Kościoła w Jerozolimie staje po stronie Piotra,

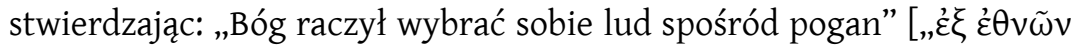

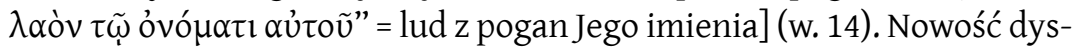
kursu Jakuba polega wszakże na tym, iż wszystkie narody, a nie jedynie Izrael, zostają nazwane „ludem Jego imienia”. Zaaplikowanie do pogan słownictwa odnoszącego się do wybrania Izraela jest paradoksem dla wiary żydowskiej. Joachim Gnilka konstatuje: „Czcigodny termin $\lambda$ aó który oznaczał lud Boży (Izrael) już w greckim Starym Testamencie, teraz otrzymuje nową treść przez to, że zostaje odniesiony do wszystkich narodów"28.

Wypowiedź Jakuba zostaje wsparta ideą zjednoczenia eschatologicznego narodów, jak zapowiedziane to zostało u proroka Zachariasza 2, 15 (LXX): „Wówczas liczne narody przyznają się do Pana i będą ludem Jego, i zamieszkają pośród ciebie, a ty poznasz, że Pan Zastępów mnie posłał do ciebie". W przywołanym fragmencie termin $\lambda$ aó na perspektywę uniwersalną. Godność ludu wybranego nie jest zatem ekskluzywnym przywilejem Izraela. Wraz z historycznym partnerem Przymierza w honorze tym mają także udział narody. Egzegeci dowodzą, iż brak rodzajnika określonego przed słowem $\lambda$ aó wprowadza ideę, iż ten nowy lud nie zastępuje starego. Cytat biblijny, który następuje, precyzuje tę myśl.

Do tej pory przemówienie Jakuba było zasadniczo streszczeniem stanowiska Piotra, teraz apostoł sięga po Pismo. Objawienie prawdy o uniwersalnym rozszerzeniu wyboru Boga musi w sposób konieczny mieć fundament biblijny. Autor Dziejów zadanie to rezerwuje dla Jakuba. Ten sięga po dwa cytaty z proroka Amosa. Końcowa część Księgi Amosa (Am 9, 11-15), z której pochodzą obydwa passusy, jest późniejszym dodatkiem z czasu wygnania lub powygnaniowym. Przez przywołanie idei restauracji eschatologicznej królestwa Dawidowego ma ona na celu złagodzenie surowego tonu wyroczni proroka. Obecność w mowie Jakuba tego wyjątkowego tekstu w całym ST nie jest przypadkowa. W odniesieniu do narodów pogańskich mówi on o wzywaniu imienia Boga bez konieczności obrzezania. Łukasz korzysta tu z tłumaczenia LXX, które

28 J. Gnilka, Teologia Nowego Testamentu, Kraków 2002, s. 260. 
odbiega od tekstu hebrajskiego. Proroctwo dotyczące restauracji królestwa Dawida, w którym Izrael ujarzmi wroga Edomitę, zostaje przekształcone przez tłumacza w zapowiedź uniwersalnego poszukiwania Boga ${ }^{29}$. W centrum przemówienia umieszczony został cytat z Am 9, 11-12. Bez wątpienia fragment ten posiada doniosłe znaczenie dla Łukasza. Ukazuje on wolę Boga dotyczącą włączenia wszystkich narodów w obietnicę daną Dawidowi i jego potomkom.

Zastosowana w tekście metafora „przybytku Dawida” odnosi się

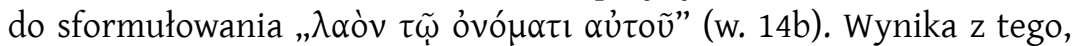
iż głos proroka nie zapowiada tu odrodzenia Jerozolimy, lecz ogłasza przyjście ludu powszechnego, który będzie adorował Boga Jezusa Chrystusa. Powyższy tekst uznawany jest za fundamentalny dla eklezjologii Dziejów ${ }^{30}$. Nawróceni poganie nie będą stanowić nowej jednostki obok Izraela, w miejsce Izraela ani też poza judeochrześcijanami. Przyjęcie przez nich wiary chrześcijańskiej zrealizuje obietnicę uniwersalizmu zbawczego daną w przeszłości Żydom.

Nawróceni, owoc misji Pawła i Barnaby, odpowiadają restauracji Dawidowej zapowiedzianej przez proroka. Konstytuują oni razem z judeochrześcijanami lud odnowiony, Izrael eschatologiczny. Od tej chwili stare oznaki tożsamości Izraela, którymi były Prawo i obrzezanie, zostały zastąpione wiarą zbawczą zrodzoną z działania Ducha Świętego (Dz 12, 12). Z tego faktu Jakub wyciąga wnioski. Nie jest rzeczą bez znaczenia, iż redaktor Łukasz czekał aż do tej chwili opowiadania, aby wprowadzić argument z Pisma odnoszący się do ewangelizacji uniwersalnej. W momencie, w którym historia chrześcijaństwa przeżywa decydujący zwrot, jest rzeczą konieczną dla Łukasza pokazanie, iż otwartość na świat pogan nie jest jakąś nowinką, lecz realizacją zbawczej woli Boga.

29 Por. D. Marguerat, Gli Atti degli Apostoli. 2 (13-28), dz. cyt., s. 105.

30 Niektórzy egzegeci proponują interpretację chrystologiczną wersetu 16 - anonsuje on restaurację znajdującego się w upadku „przybytku Dawida”, postrzegając w nim zapowiedź zmartwychwstania Chrystusa i Jego wywyższenie po prawicy Boga. Zdaniem większości komentatorów nie ma jednak w tekstach Łukaszowych śladów takiej interpretacji. Wystąpienie Jakuba nie mówi zatem o Chrystusie, ale odnosi się do rzeczywistości Kościoła i jego otwartości na uniwersalizm zbawczy. 
Decyzja Jakuba na swój sposób formułuje argument Piotra z wersetu 10 na temat jarzma, którego nie powinno się nakładać na uczniów:

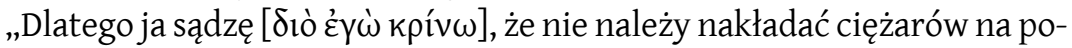
gan, nawracających się do Boga” (w. 19). Zastosowane tu słowo „кpívw” (sądzę, uważam) ma podwójne znaczenie: wyrażonej opinii oraz zakomunikowania decyzji o charakterze prawnym. Głowa Kościoła w Jerozolimie ratyfikuje oświadczenie Piotra, lecz bez negatywnego twierdzenia odnoszącego się do możliwości realizacji wymagań Prawa. Decyzja zostaje zakomunikowana listem, którego treść zawierają wersety 23b-29.

Po wersecie 20 następuje to, co nie autor Dziejów, lecz późniejsza tradycja chrześcijańska nazwała „dekretem apostołów”. Oczywiste jest jego znaczenie dla Łukasza, gdyż zostanie przywołany on jeszcze w Dz 16, 4, a jego treść powtórzona w Dz 15, 29 i 21, 25. Dekret stanowi chrześcijański kodeks moralny, jeden z najstarszych, jaki się zachował. Rozporządzenie nakazuje cztery wstrzemięźliwości ${ }^{31}$ : powstrzymania się od ofiar składanych bożkom, od krwi, od tego, co uduszone, i od nierządu (Dz 15, 29). „Zrezygnowano z konieczności obrzezania, czego domagali się żydujący, a nałożono wymagania mniej ważne, ponieważ odnoszące się w trzech przypadkach do spożywania posiłków i w jednym do związków małżeńskich między osobami o zbyt bliskim pokrewieństwie. [...] Wydaje się, że cztery klauzule Jakubowe należy uznać za wyraz kompromisu, do jakiego doszło we wczesnym chrześcijaństwie między chrześcijanami z żydostwa a chrześcijanami z pogaństwa. Jest to prawdopodobnie cel, jaki przyświeca Łukaszowi przy redagowaniu Dz 15"32.

Gdy chodzi o rolę dekretu, należy zauważyć, iż kryzys miał charakter soteriologiczny. Decyzja eklezjalna nie warunkuje przystępu do zbawienia, lecz proklamuje zasady, których należy przestrzegać, aby zachować czystość, jakiej Bóg udzielił nie-Żydom na podstawie łaski (Dz 15, 9). Cztery wstrzemięźliwości wpisują się w kontekst etyczny, ustanawiając normy wspólnego życia pomiędzy judeo- i etnochrześcijanami. Nie chodzi tylko o „wspólnotę stołu”, ale także o wspólne życie, jedność

31 Por. B. Marconcini, Verità e carità al concilio di Gerusalemme (At 15, 1-35), w: Atti degli Apostoli, a cura di M. Crimella, Padova 2013, s. 224.

32 W. Rakocy, „Będziecie moimi świadkami...”, dz. cyt., s. 40. 
Kościoła. Ta „decyzja synodalna” nie warunkuje przystępu do zbawienia, lecz proklamuje zasady, których należy przestrzegać we wspólnotach mieszanych, aby zachować czystość, jakiej Bóg udzielił nie Żydom na podstawie łaski (Dz 15, 9).

Podczas gdy mowa Piotra, ratyfikowana przez Jakuba, miała na celu zachowanie etnochrześcijan od konieczności nałożenia na nich brzemienia Prawa Mojżeszowego (Dz 15, 10.19), cztery wstrzemięźliwości strzegły strony judeochrześcijańskiej od potencjalnego skalania ze strony etnochrześcijańskiej. Widoczne są tu dwa ważne przesunięcia: przechodzi się od soteriologii do etyki i od praw etnochrześcijan do praw judeochrześcijan. Potwierdzają one tezę, iż tekst Łukaszowy łączy w sobie dwa różne czasowo zdarzenia: sobór jerozolimski poświęcony kwestii obrzezania i wolności od Prawa chrześcijan pochodzenia pogańskiego oraz wydany później dekret nakładający na pogan cztery warunki regulujące współżycie wspólnot mieszanych, co sugeruje Paweł w Gal 2, 1-10 i 11-14 $4^{33}$.

\subsection{Decyzja - „dekret apostolski” jako natchniony chrześcijański kodeks moralny (Dz 15, 22-29)}

Punkt widzenia Jakuba przekształca się w decyzję eklezjalną obejmującą całą wspólnotę Kościoła. Sformułowanie, jakiego w wersecie 28 używa Łukasz: „wydawało się dobre” [ย̌ $\delta \circ \xi \varepsilon]$, to forma bezosobowa rozpowszechniona w grece, odpowiadająca czasownikowi „decydować”. A zatem pierwotna wspólnota po „debacie synodalnej” podjęła eklezjalną decyzję. Apostołowie i starsi piszą w imieniu Kościoła. Adresatami dekretu są chrześcijanie pochodzenia żydowskiego, ponieważ to ich dotyczył konflikt. Ważne jest sformułowanie wprowadzające w dokument:

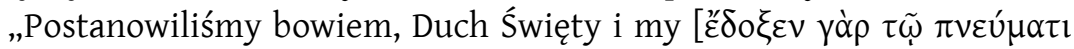

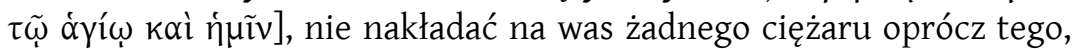
co konieczne" (w. 28). Łukasz usilnie stara się ukazać, iż przemianami w życiu Kościoła kieruje Duch Święty. Formuła „Duch Święty i my”

33 Na pytanie o rozwiązanie różnic między tekstami Dz 15, 1-33 a Gal 2, 1-10 odpowiada W. Rakocy, Tak zwany Sobór Jerozolimski wyrazem troski o jedność pierwotnego Kościoła, „Roczniki Teologiczne" 43 (1996) z. 1, s. 142-144. 
(pojawiła się ona już w Dz 5, 32) wydaje się „teologicznie niebezpieczna”. Niemniej jednak nie zawłaszcza ona Ducha, lecz chroni przed przypisaniem decyzji wyłącznie postanowieniu instytucji. Zarządzający wspólnotą Kościoła stają się mediatorami dekretu spisanego pod natchnieniem Ducha. Odrzucono radykalne stanowisko, które nakazuje przyjęcie obrzezania i zachowywanie rytuałów żydowskich jako koniecznych dla zbawienia (Dz 15, 5). Delegacja udaje się do Antiochii i przekazuje pismo całemu tamtejszemu Kościołowi. Decyzja eklezjalna wyrażona w dekretach zostaje przyjęta pozytywnie. Opowiadanie kończy się informacją, iż chrześcijanie antiocheńscy cieszą się z zawartego porozumienia.

Za Carlem Marią Martinim dodajmy, iż w dekrecie „nie chodzi o powszechne wymagania moralne, lecz pozytywne nakazy Prawa Mojżeszowego o charakterze rytualnym i ustawowym, których zachowywania z motywów jedności Kościoła wymaga się także od pogan. Zakazy te nie mają znaczenia czysto prawnego, nie są jedynie czystą akceptacją obrzędów. Oznaczają one [...] wolę uniknięcia jakiegokolwiek kontaktu z idolatrią, wystrzegania się urażenia bliźniego oraz jakiegokolwiek nieuporządkowania w dziedzinie seksualnej. Ścisłe rozróżnienia pomiędzy wymaganiami obrzędowymi a normą moralną są już naszymi" ${ }^{34}$. „Tzw. Sobór Jerozolimski, opisany przez Łukasza w Dz 15, z jednej strony uznaje wolność pogan od Prawa, z drugiej strony zaś chroni także żydowską tradycję religijną, mając na względzie dobro całego Kościoła. W tym kontekście dekret z czterema warunkami jest przykładem porozumienia osiągniętego pomiędzy chrześcijanami pochodzenia żydowskiego i pogańskiego, gdzie ci drudzy podjęli się zachowywania czterech klauzul, a pierwsi mogli za to bez wyrzutów sumienia uczestniczyć z nimi we wspólnocie stołu"35.

Zakończmy ten punkt wskazaniem Benito Marconciniego, które dotyczy aktualności tematu podjętego w artykule: „Kościół czasu Soboru w Jerozolimie, który widzi, ocenia i działa, podejmuje problemy bez ich

34 C. M. Martini, Il decreto del concilio di Gerusalemme, w: Fondamenti biblici della teologia morale. Atti della XXII Settimana biblica (della) Associazione Biblica Italiana, Brescia 1973, s. 350.

35 W. Rakocy, Tak zwany Sobór Jerozolimski wyrazem troski o jedność pierwotnego Kościoła, „Roczniki Teologiczne” 43 (1996) z. 1, s. 147-148. 
ukrywania oraz rozwiązuje je w wyważonym połączeniu prawdy, wolności i miłości, stanowi konieczny punkt odniesienia dla wspólnoty chrześcijan każdego czasu" ${ }^{\prime \prime}$.

\section{Dz 15, 1-35 - nieodzowne źródło inspiracji w procesie decyzji eklezjalnej w obliczu nowych wyzwań}

Podjęte $\mathrm{w}$ artykule zagadnienie rozeznawania eklezjalnego stanowi przedmiot refleksji w ważnym, współczesnym dokumencie Kościoła, wypracowanym przez Papieską Komisję Biblijną: Biblia a moralność. Biblijne korzenie postępowania chrześcijańskiego z roku 2008. Wychodzi się w nim z założenia, iż „w rozeznaniu moralnym należy wziąć pod uwage stopniowe udoskonalenie sumienia moralnego, w szczególności w lekturze obu Testamentów” oraz „dla Pisma Świętego istotnym miejscem rozróżnienia jest wspólnota" ${ }^{37}$. W odniesieniu do świadectwa Nowego Testamentu na temat rozeznania eklezjalnego dokument odwołuje się do przeanalizowanej przez nas narracji Dz 15, 1-35. Biblia a moralność wyszczególnia istotne etapy drogi podjętej przez uczestników soboru jerozolimskiego, nazywając akt pierwotnej wspólnoty chrześcijańskiej „roztropnym rozeznaniem: drogą wspólnotową, poszukiwaniem rozwiązania i podjęciem decyzji" ${ }^{38}$. Warto przywołać tu elementy rozeznania wspólnotowego wyróżnione w Dziejach Apostolskich przez dokument Biblia a moralnośćs: (1.) Apostołowie i starsi zbierają się, aby przeanalizować problem. Dzisiaj ten typ postępowania wyrażają terminy „współodpowiedzialność" i „synodalność”; (2.) W celu znalezienia właściwego rozwiązania kwestii spornej odpowiedzialni rozróżniają pomiędzy tym, co pilne (zasadnicze wartości, które należy zachować), a tym, co możliwe (ewentualność przyjęcia tego przez każdą ze stron). W akcie rozeznania wspólnotowego uczestniczą trzy strony: Piotr, Paweł i Barnaba oraz

\footnotetext{
B. Marconcini, Verità e carità al concilio di Gerusalemme (At 15, 1-35), dz. cyt., s. 225.

Papieska Komisja Biblijna, Biblia a moralność..., dz. cyt., s. 151-152.

Papieska Komisja Biblijna, Biblia a moralność..., dz. cyt., s. 152.

Papieska Komisja Biblijna, Biblia a moralność..., dz. cyt., s. 152.
} 
Jakub. Piotr daje orientację fundamentalną, powołując się na trzy motywy teologiczne (kriterion): Bóg nie czyni różnicy między osobami, nie wyklucza; Duch Święty dokonał tych samych znaków wśród pogan, jak i Hebrajczyków; wiara jest darmo dana przez Boga (Dz 15, 7-11). Paweł i Barnaba mówią na mocy doświadczenia, językiem autopsji (Dz 15, 12). (3.) Kompromis proponuje Jakub, domagając się nie nakładania dodatkowych ciężarów, lecz unikania zgorszeń i uwzględnienia jednych i drugich (Dz 15, 13-21). Jest to konsensus rozwiązujący sytuację kryzysową. Dokument mówi w odniesieniu do stanowiska Jakuba o otwartości na odmienność, na swego rodzaju pluralizm socjologiczny, który został przygotowany poprzez starotestamentowy temat obrzezania serca (Pwt 10, 16; Jer 4, 4; por. Rm 2, 25-29). (4.) Na koniec, listem okólnym, komunikuje się Kościołowi rezultat rozeznania wspólnotowego (Dz 15, 23-29).

Dokument Papieskiej Komisji Biblijnej eksponuje zatem cztery wciąż aktualne kroki decyzji eklezjalnej obecne w Łukaszowej narracji: nazwanie przyczyny trudności, którą stanowią decyzje podjęte poza łącznością z Kościołem (por. Dz 15, 24); ro z e zn a n i e du chow e: „Duch Święty i my" podjęte na modlitwie i naradzie (Dz 15,28); ot wart ość na szerszą konsultację, która angażuje cały Kościół (Dz 15, 22); a także wezwanie do sumienia moralnego wspólnot, do których posłano orędzie (Dz 15, 29b). 


\section{Summary}

\section{Przyjęcie wykluczonych do wspólnoty zbawienia na przykładzie Dz 15, 1-35}

Celem artykułu było ukazanie sposobu postępowania wspólnoty pierwotnego Kościoła wobec problemu przyjęcia do wspólnoty zbawienia wykluczonych wcześniej pogan. Kwestia ta stanowiła wielkie wyzwanie teologiczne, pastoralne i normatywnodyscyplinarne dla chrześcijaństwa początków. Zagadnienie przedstawione zostało w trzech punktach. $\mathrm{Z}$ uwagi na fakt, iż przedmiotem rozważań był eklezjalny proces decyzyjny dotyczący norm postępowania, w punkcie pierwszym zdefiniowane zostało pojęcie decyzji moralnej w jej trójwymiarowości czasowej. Stwierdziliśmy, że rozpoznanie

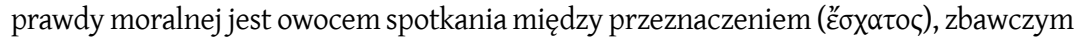
działaniem Chrystusa (крıт́́pıov) oraz rzeczywistością wymagającą przemiany (кoıрó)). W centralnym, drugim punkcie ukazano paradygmat procesu eklezjalnej decyzji, którego owocem było pełne włączenie do wspólnoty Kościoła wykluczonych etnochrześcijan. Kościół czasu soboru w Jerozolimie na „sposób synodalny” podjął problem wykluczonych i rozwiązał go w wyważonym połączeniu prawdy, wolności i miłości, stając się pod tym względem koniecznym punktem odniesienia dla procesu rozeznawania wspólnoty chrześcijan każdego czasu. Przypomniano o tym w trzecim punkcie artykułu, który dedykowany został aktualnym wskazaniom na temat rozeznawania wspólnotowego zawartym w dokumencie Biblia a moralność. Wskazano w nim, iż Pismo Święte, niezbędne źródło inspiracji dla procesu rozeznawania eklezjalnego, nadal stanowić powinno konieczny punkt odniesienia dla rozwiązywania przez Kościół nowych, aktualnych problemów etycznych. Celem najważniejszym, który udało się osiągnąć, było zaproponowanie synodalności, starożytnej kościelnej metody rozeznawania, chrześcijańskiej „kultury dialogu i spotkania” jako skutecznej metody przezwyciężania degradującej współczesną cywilizację „kultury wykluczenia”"

Słowa kluczowe: wykluczeni, sobór w Jerozolimie, uniwersalizm zbawczy, synodalność

Acceptance of the Excluded in the Community of Salvation.

Study Case of Acts 15, 1-35

The aim of the article is to examine the way, in which the community of the Church acted in confrontation with a huge theological, pastoral, normative, and disciplinary

40 Por. Franciszek, Przemówienie podczas spotkania z przedstawicielami Organizacji Narodów Zjednoczonych, Siedziba ONZ, Nowy Jork, 25.09.2015, http://w2.vatican.va/content/francesco/pl/speeches/2015/september/documents/papa-francesco_20150925_onu-visita.html (19.07.2018). 
challenge set in front of the early Christianity by an ethical issue of accepting into the community of salvation those, who were excluded so far, i.e. pagans.

The issue has been approached in three points. As the issue in question deals with the ecclesiastical process of taking decisions around norms of behavior, the first point brings a definition of a moral decision in its three-dimensional time structure. In the second, the central point of the paper, a paradigm for an ecclesiastical decision making process has been presented. The reflection has been based on the narrative from Acts 15, 1-35 concerning Jerusalem Council, a process that brought excluded ethno-Christians to the community of the Church. The third, final point of the analysis has been dedicated to the present issues of a communitarian discernment, as they are presented in a document of the Pontifical Biblical Commission The Bible and Morality. The document presents the Holy Bible as an indispensable source for the ecclesiastical discernment process, and as a necessary point of reference for the new ethical issues.

Keywords: excluded, the council of Jerusalem, the universalism of salvation, synodality

\section{Bibliografia}

Barbaglio G., Conflittualità e riconciliazione nelle prime comunità cristiane, w: G. Barbaglio, Emozioni e sentimenti di Gesù, Bologna 2009, s. 199-210.

Fabris R., Atti degli Apostoli, Brescia ${ }^{6} 2004$.

Gnilka J., Pierwsi chrześcijanie. Źródła i początki Kościoła, Kraków 2004.

Gnilka J., Teologia Nowego Testamentu, Kraków 2002.

Lausberg H., Retoryka literacka. Podstawy wiedzy o literaturze, tłum. A. Gorzkowski, Bydgoszcz 2002.

Maceri F., La coscienza morale filiale, w: Figli nel Figlio. Una teologia morale fondamentale, a cura di R. Tremblay, S. Zamboni, Bologna 22016, s. 225-248.

Marconcini B., Verità e carità al concilio di Gerusalemme (At 15, 1-35), w: Atti degli Apostoli, a cura di M. Crimella, Padova 2013, s. 218-225.

Marguerat D., Steffek E., L'avvento della salvezza universale in Luca-Atti, w: Una salvezza a misura dell'universo. Scritti in onore di Gérard Rossè, a cura di G. Ibba, Roma 2015, s. $139-162$.

Marguerat D., Gli Atti degli Apostoli. 2 (13-28), Bologna 2015.

Martini C. M., Il decreto del concilio di Gerusalemme, w: Fondamenti biblici della teologia morale. Atti della XXII Settimana biblica (della) Associazione Biblica Italiana, Brescia 1973, s. 345-355.

Papieska Komisja Biblijna, Biblia a moralność. Biblijne korzenie postępowania chrześcijańskiego, Kielce 2009.

Pindel R., Mowy obronne św. Pawła w Dziejach Apostolskich. Analiza retoryczna Dz 24 i 26 w kontekście zastosowania retoryki w biblistyce, Kraków 2012.

Rakocy W., ,Będziecie moimi świadkami...” (Dz 1, 8). Dzieje Apostolskie, w: Wprowadzenie w myśl i wezwanie ksiag biblijnych. 9. Dzieje Apostolskie. Listy św. Pawła, red.J. Frankowski, S. Mędala, Warszawa 1997, s. 13-81. 
Rakocy W., Tak zwany Sobór Jerozolimski wyrazem troskio jedność pierwotnego Kościoła, „Roczniki Teologiczne” 43 (1996) z. 1, s. 139-148.

Rossé G., Atti degli Apostoli commento esegetico e teologico, Roma 1998.

Szymik S., Mowy w Dziejach Apostolskich, w: Encyklopedia katolicka, t. 13, red. E. Gigilewicz, Lublin 2009, kol. 377-378.

Vidal M., Manuale di etica teologica.1. Morale fondamentale, Assisi 1994. 